\title{
A Note on the A.V.(1611) Translation of Romans 12:3
}

\author{
SAMUEL G. HORNSBY, JR.
}

By the summer of 1604 , King James had appointed "certain learned men to the number of four and fifty" to undertake the preparation of a new Bible. The translators were divided into six companies and charged with fifteen rules. ${ }^{1}$ The first and the fourteenth concerned existing translations of Scripture which the translators of the 1611 Bible were to follow.

1. The ordinary Bible read in the Church, commonly called the Bishops' Bible, to be followed, and as little altered as the truth of the original will permit.

14. These translations to be used when they agree better with the text than the Bishops' Bible: Tyndale's, Matthew's, Coverdale's, Whitchurch's, Geneva. ${ }^{2}$

Dr. Ward Allen has recently published an edition of the Lambeth Palace MS. 98, an English translation of the Epistles, prepared by the New Testament company at Westminster, in which he identifies the sources of diction and syntax of the A. V. Of special interest are the spots in the A. V. which were either an invention of the translators or were from some source other than the Bibles specified in King James's rules. ${ }^{3}$ Romans 12:3 is such a verse; it read this way in the A. V.:

For I say, through the grace given unto me, to every man that is among you, not to think of himself more highly than he ought to think; but to think soberly, according as God hath dealt to every man the measure of faith. ${ }^{4}$

The phrase having no apparent source is not to think of himself more highly than he ought to think [but] to think soberly, which appears in MS. 98 as that no man be over-wyse, more then he ought to be wyse, but to be wyse to sobriety.-5 In the early versions one finds the following variations: 
Tyndale: that noman esteme of him selfe moare then it becometh him to esteme: but that he discretely judge of him selfe, ...

Great Bible: that noman stonde hye in his owne conceate, more than be commeth hym to esteme of him selfe: but so judge of hym selfe, that he be gentle and sober,....

Geneva (1557): that no man esteme of hym selfe, more than it becometh him to esteme, but that he discretely judge of him selfe, ....

Geneva (1560): that no man presume to understand above that which is mete to understand, but that he understand according to sobrietie, .... Bishops': that no man esteeme of himselfe, more then hee ought to esteeme, but so esteeme himselfe that he behave himselfe discreetly,.... Rheims: not to be more wise then behoveth to be wise, but to be wise unto sobrietie, ...6

That the wording of Romans 12:3 was on the minds of the A.V. translators there is no doubt. John Bois, a translator who made notes while the company of review prepared the final edition of their translation at Stationers' Hall during 1610-1611, identifies the problem:

\section{Cap. $12.3 \nu \eta \gamma \pi \epsilon \rho \phi \rho \circ \gamma \epsilon \iota \gamma$ [not to think more highly]}

These words condemn both arrogance and inquisitiveness: inquisitiveness truly both in inquiring into subtle things, and in pursuing those things which do not pertain to us and our office. ${ }^{7}$

the note makes it certain that the translators wanted to weave double meaning, the notion of inquisitiveness as well as of arrogance, into the passage; and the phrasing of the sources at hand seems to have been insufficient to bear the weight of the intended ambiguity. Did then the translators supply an invention of their own? Possibly not. In 1568, the commentary on Romans by Vermigli or "Peter Martyr" had been translated into English. ${ }^{8}$ Although there is no evidence that the translators used the commentary in any extensive way, the following example makes it possible to suppose that Peter Martyr's work was from time to time consulted by the king's learned men.

In the commentary, Romans $12: 3$ is rendered in a fashion that is not unlike that of the A.V. ${ }^{9}$

For I say through the grace that is given unto me, to every one that is amongst you, that no man presume or think of him selfe more than he ought. For we ought to be wise unto sobriety as God has dealt to every man the measure of faith. ${ }^{10}$

The critical explanation which follows embraces both of the meanings which are discussed by Bois:

That is we ought to think moderately and temperately of ourselves ... not [only] the temperance whereby we moderate pleasures in 
meat and drink and carnality: but whereby we bridle our affects, and lusts, and all our actions.... And doubtless they which loose the bridle to arrogance, and think higher of themselves than is meet, are destitute of their accustomed prudence and become mad ....

The passage concludes:

For we offend in that sin not only in our actions and in the executing of duties, but also in the study of knowledge and of understanding. For there are many which neglecting the care of knowing things necessary, unprofitably wander in things unfruitful and vain .... This oftentimes happeneth in overmuch busying ourselves in curious things whilest we go about to search out these things which nothing pertain unto us, we to our shame are ignorant of other things which are profitable and necessary .... They also break the commandment of the Apostle which in things profitable and necessary to salvation will be wiser than they ought to be. For there are some which search out things pertaining unto Christian faith with greater study than is needful. For they will not be content with those things which are set forth in the holy scriptures: but according to rashness of human reason will either add somewhat to the words of God, or pluck something therefrom.

Did the A. V. translators turn to Peter Martyr for their phrasing at Romans 12:3? It is not known for certain that they did. What can be known for certain is that Peter Martyr's turn of phrase, [to] presume or think of him selfe more than he ought, incorporated for Vermigili and seemingly for the 1611 translators a web of meaning. And as Miles Smith reminds all readers of Scripture in the preface to the 1611 version, the cultivation of ambiguity is sometimes a necessary part of Biblical translation theory: ". . . it hath pleased God in his divine providence, here and there to scatter words and sentences of that difficulty and doubtfulness, not in doctrinal points that concern salvation ... but in matters of less moment .... [Thus] it is better to make doubt of those things which are secret than to strive about those things that are uncertain." 11

\section{LaGrange College}

\section{Notes}

1 For a complete list, see A. W. Pollard, Records of the English Bible (London: O.U.Y., 1911), pp. 53-55.

2 The text of the New Testament in Matthew's Bible is Tyndale's final correction, 1534-35; "Whitchurch" stands for the Great Bible. See Pollard, pp. 14, 23. Coverdale's 1535 rendering is only a slight variation from that of the Great Bible of 1539: ". . that no man esteme off him selfe more, then it becometh him to esteme: but that he discretly iudge of himselfe, accordinge as God hath dealte unto euery man the measure of faith" (a facsimile edition of The Coverdale Bible: 1535, ed., S. L. Greenslade [Folkestone, Kent: W. Dawson \& Sons, 1975]). 
3 Translating the New Testament Epistles 1604-1611: A Manuscript from King James's Westminster Company (Published for Vanderbilt University Press by University Microfilms, 1977).

4 The quotations from the A. V., Tyndale, the Great Bible, Geneva (1560), Bishops', and Rheims are those reprinted in The New Testament Octapla, ed. Luther Weight (New York: Thomas Nelson \& Sons, n. d.). The Geneva (1557) text comes from The English Hexapla (London: Samuel Bagster \& Sons, 1841).

5 Allen, New Testament Epistles, p. 36.

6 The influence of the Rheims needs to be noted. Allen (New Testament Epistles, p. 319) counts 1255 revisions of the Bishops' Bible in the Epistles of the A. V. which come from the Rheims N.T.

7 The notes of John Bois have been translated and edited by Ward Allen in Translating for King James (Nashville: Vanderbilt University Press, 1969). Bois comments on sixteen verses in Romans which remained to be settled by the final review company.

8 Most learned and fruitfull Commentaries of D. Peter Martir Vermilius Florentine ... upon the Epistle of $S$. Paul to the Romanes .. . . Lately tra[n] slated out of the Latine into Englishe, by H. B. (Imprinted at London by John Daye, 1568.) It is not known that the influence of Peter Martyr came through a particular individual working in the Westminster company. However, it seems not unlikely that his work was familiar to the king's translators since he served as Regius professor of divinity at Oxford after being brought to England by Cranmer and since he was consulted about the Prayer Book and canon law reforms. It is also possible that Vermigli was known to the translators through his influence on Immanuel Tremellius, whose Latin versions of the Old and New Testaments lay before the revisers as they worked (Pollard, p. 61).

9 Romans $12: 3$ is the single passage of the sixteen in Bois where there is a possible indebtedness. However, I have found five additional places in MS. 98 which may have their origin in Peter Martyr's commentary: $3: 19 ; 5: 14 ; 7: 4 ; 8: 25 ; 8: 29$. In each of the five verses the possible indebtedness hinges on one or two words. For example, at 8:25, the A. V. use of wait cannot be traced to any one of the Bibles offered for consultation. In Vermigli's verse one finds "we do with patience wayt for it" [italics mine].

10 The passage from Scripture and related commentary are found on p. $415^{\mathrm{a}-\mathrm{b}}$. Spelling has been slightly but silently modernized and letters normalized to conform with modern usage.

11 Pollard, p. 372. The spelling is modernized. 